\title{
Attitudes and Motivation of Chadian Learners of English
}

\author{
Gilbert Tagne Safotso ${ }^{1 * *} \&$ Ndoubangar Tompte ${ }^{2}$ \\ ${ }^{1}$ Department of Foreign Applied Languages, University of Dschang, Cameroon \\ ${ }^{2}$ Department of English, University of Maroua, Cameroon \\ *Correspondence: P O Box 282, Dschang, Cameroon. E-mail: gilbertsafotso@gmail.com \\ Received: March 19, $2018 \quad$ Accepted: April 7, $2018 \quad$ Online Published: April 25, 2018 \\ doi:10.5430/wje.v8n2p174 \\ URL: https://doi.org/10.5430/wje.v8n2p174
}

\begin{abstract}
The spread of English as a world language has reached many non English speaking countries. In the Expanding Circle (Kachru, 1988), many countries in Africa demonstrate more and more interest in learning it. This paper investigates Chadian learners' attitudes and motivation in learning that language. The study's subjects are made up of 190 secondary / high school learners and 70 university students. The analysis is based on Gardner's and Lambert's (1972) integrative and instrumental motivation model. Results showed that both female and male students at secondary /high school and university levels have a positive attitude towards English. They all have a high instrumental motivation and their interest in learning English for communicative and traveling purposes is quite significant.
\end{abstract}

Keywords: attitudes, instrumental motivation, job, communication, educational system

\section{Introduction}

There are many reasons for studying a second or a foreign language. Some people take it just as a school subject while others learn it to get a job, for traveling purposes, for business, pleasure or other purposes. In Chad, English is not an official language, but since the beginning of oil exploitation in the south of the country in 2003, many companies whose working language is English have been recruiting a lot of local manpower. Those companies include the American Exxon Mobile, Chevron, Malaysian Petronas and Chinese CNPC. Chadian job seekers who want to work with them need to master English. Though for some time the country has been experiencing economic crisis because of the low cost of petrol on the international market, for over a decade now, Chadian learners have been rushing for English. This paper investigates their attitudes and motivation towards the learning of that language.

\section{Brief review of Some Literature on Attitudes and Motivation Towards Language Learning}

The Longman Dictionary of Language Teaching and Applied Linguistics (2002: 297) defines language attitudes as the opinion that speakers of different languages or language varieties have towards each other's languages or to their own language. Expressions of positive or negative feelings towards a language may reflect impressions of linguistic difficulty or simplicity, ease or difficulty of learning, degree of importance, elegance, social status, etc. Attitudes towards a language may also show what people feel about the speakers of that language. They may have an effect on second or foreign language learning. The measurement of language attitudes provides information which is useful in language teaching and learning. The feelings may be good, bad or neutral. They may favor or hinder the effective learning process.

Motivation is often seen as one of the key elements which influence the rate of success of second or foreign language learning. Gardner \& Lambert (1972) laid the foundation for research in that area. They distinguish two major kinds of motivation that could be related to L2 learning: integrative and instrumental motivation. The first motivation reflects the learner's will to be like a representative member of the other language community. It also shows the learner's high level of effort to learn the language of a valued L2 community in order to communicate with the members of that group. The second or instrumental motivation, is prompted by the desire to gain social recognition or economic advantages by knowing an L2 (Gardner \& Lambert, 1972). It is learning an L2 for pragmatic and utilitarian benefits such as a high salary, power, or career (Johnson, 2001). 
In learning a new language, both types of motivation are important. A learner might learn an L2 well with an integrative motivation or instrumental one, or with both (Crookes, 1991). Brown (2001) points out that instrumental and integrative motivation are not exclusive. Learners generally combine both orientations. As example, he cites an international student learning English for Academic Purposes in the United States, who at the same time wishes to become a member of the target language community. Dörnyei (1994) argues that L2 learning presents a unique situation due to the multifaceted nature and role of language. It is at the same time: (a) a communication coding system that can be taught as a school subject, (b) an integral part of the individual's identity involved in all mental activities, and also (c) the most important channel of social organization embedded in the culture of the community where it is used (p. 274). In addition to the two types of motivation, Dörnyei mentions that there are other components of L2 motivation including the cognitive ones. Motivational components that are specific to learning situations involve (a) the course specific, (b) the teacher-specific, and (c) the group-specific components. The course-specific motivational component concerns the syllabus, the teaching materials, the teaching method and the learning tasks. The teacher-specific component concerns the teacher's personal teaching style, feedback and relationships with students, and the group-specific component is related to the dynamic of the learning group (Dörnyei, 1994, p.277). In the literature on language learning motivation, there is also a distinction between intrinsic and extrinsic motivation (Dörnyei, 2001). Individuals perform extrinsic behaviors for example to receive good grade or to avoid a punishment. Intrinsic motivation deals with internal factors such as studying English for professional development.

Attitude plays a crucial role and can influence success or failure in language learning. Weinburgh (1998) believes that attitudes towards learning influence behaviors such as selecting and reading books, or speaking in a foreign language. Learners' attitudes generally dictate whether or not they will be able to absorb the details of a new language. In other words, achievement in a target language relies not only on intellectual capacity, but also on the learner's attitudes towards language learning. In learning a second language, it is thus important that students have high motivation and positive attitude towards the target language to better succeed in it. Alizadeh (2016) reviewed a number of studies on the role of motivation in second and foreign language, and suggested that teachers should teach their learners how to promote it. They should also help their learners find motivation in areas where they do not expect any (p. 14).

Recent studies on attitudes and motivation of learners towards the learning of a second foreign language include Cheng \& Dörnyei (2007), Karachan (2007), Lamb (2007 \& 2011), Murphy and Carpenter (2008), Fen \& Chen (2009), Ghazvini \& Kajehpour (2011), Babaee (2012), Goktepe (2014), Drbseb (2015), Tasgin \& Tune (2018). All those studies show that learners generally have a positive attitude towards English, and are instrumentally motivated to learn it. Ghazvini \& Kajehpour (2011) investigated the attitudes and motivation of Iranian high school learners towards the learning of English. The findings showed that Iranian female students have a more positive attitude towards English than boys. They are equally more integratively motivated than them. Iranian male students are essentially instrumentally motivated to learn English. Tasgin \& Tune (2018) report that Turkish secondary school students engage more in English and Turkish than mathematics. Babaee's (2012) study is a kind of state of the art paper which reviews major studies on motivation in learning a second language from a historical perspective starting from Gardner \& Lambert (1959) to 2012. The section below looks at the Chadian educational system to better understand the subjects' attitudes and motivation.

\section{The Chadian Educational System}

In Chad, the educational system is patterned on that of France. The languages of instruction are French and Arabic. Primary school education lasts for six years, followed by general secondary education, which lasts for seven years, or technical and vocational secondary education which has varying duration. English is compulsory just from Sixième (equivalent of Form I) to Terminale (equivalent of Upper Sixth) for three to four hours a week. The vast majority of Chadian students thus start the learning of English in secondary school.

At university level, only the universities of N'Djamena and Doba have full departments of English. Other Chadian universities include Adam Barka of Abéché, Moundou, and Sarh where they offer degree programs in history-geography, modern literature, French, Arabic and French, mathematics, physics, chemistry, engineering, business, law and biology-geology.

Chad also has a number of higher institutes: Institut Universitaire des Sciences et Techniques of Abéché, Institut Universitaire des Sciences Agronomiques et de l'Environnement of Sarh, Institut Universitaire Polytechnique of Mongo, Institut Universitaire of Biltine, Institut Universitaire of Mao, Institut des Sciences de l'Education, Institut 
Universitaire des Sciences Agronomiques of Laï, Institut du Sahara et du Sahel of Iriba, Institut Universitaire Polytechnique de l'Elevage of Moussoro. The higher training colleges include: École Normale Supérieure of N'Djaména (where a department of English also exists), École Normale Supérieure des Sciences of Bongor, École Normale Supérieure of Sarh, École Normale Supérieure of Abéché, École Nationale d'Administration et de la Magistrature of N'Djaména, École Nationale des Travaux Publics of N'Djaména, ENTP, École Nationale des Télécommunications of Sarh, and École Nationale de la Santé Publique. Those institutions train secondary school teachers, civil administrators, public work technicians, post and telecommunication agents and medical doctors. In some of them, they teach some English for specific purposes.

At independence in 1960, the Chadian government established a goal of universal primary education, and school attendance was made compulsory. Unfortunately, the development of standard curricula was hampered by the limited number of schools and the muslims' preference for koranic schools, which throughout the Saharan and Sahelian zones teach students to read Arabic and recite koranic verses.

Despite the government's efforts, the overall educational level remains low throughout the country. Wars and many other problems have hindered the development of Chadian education since independence. Financing has been very limited. Reduced facilities and personnel have made it difficult for the educational system to provide adequate instruction. Poor infrastructures have generated over-crowded classes in rural schools, some of which host 100 to 200 students per class (World Bank, 2007). It is a situation where three or four learners sit on each desk, and others sit around it or even stand during the lessons.

The problem is not only that of lack of classrooms and teachers. The quality of the existing teaching staff is poor, and this is due, in part, to the lack of trained teachers. Unqualified community teachers (maittres communautaires) and part-time staff (enseignants vacataires) make up $70 \%$ of the total workforce. At secondary school level, the situation is even worse. The following statistics give a summary of the overall educational system.

At the level of primary school, there are three types of schools in Chad: (1) public schools owned by the government which generally offer poor teaching; (2) private schools owned by missionaries or some business men which offer an average quality teaching; (3) the third category of primary schools is made up of community schools set up by local organizations with the support of the government through the Ministry of Education. Statistics from the Ministry of Education show that in the academic year $2008 / 2009$ there was a total of 7854 primary schools in the country distributed as follows: 3559 (45.31\%) public schools, 494 (06.31\%) private, and 3801 (48.39) community schools. So, in Chad, the majority of children start their primary school education in community or public schools where the quality of teaching is reputedly poor.

At secondary school level, sources from the Ministry of Education indicate that in 2010, the number of public secondary and high schools throughout the country was only 74 (49 secondary and 25 high schools) for a vast country like Chad (a situation which is almost the same today). The raw rate of schooling at that level was $32 \%$ in 2009 against $19 \%$ in 1990 . To date, only about $20 \%$ of girls and $45 \%$ of boys aged 12 to 19 are in secondary schools (World Bank, 2007). Over $50 \%$ of Chadian learners thus do not go beyond primary school level. Mbaiosso (1990) remarks that in Chad, education is elitist and vague, and that there is a high rate of repeating and drop out, youths' prevailing unemployment and under-employment despite imperious needs of trained workers.

Another critical remark on the Chadian educational system is by Djimrassem (2015). He points out that in Chadian schools nowadays, falling standards, corruption, students' de-motivation towards reading, insufficient educational policy and students' difficulties to choose their field of study in spite of educational seminars and forums held here and there are rampant. Chadian schools have become those of unemployment and underdevelopment, with qualified leavers working as bar and café owners, hawkers, security agents etc. for survival. So, because of the poor educational system briefly described above, learning English in Chad today can open "technological doors, educational doors, and even 'locational' doors" (Anderson, 2008: 13).

\section{Method}

The data analysed was collected through a questionnaire administered to secondary / high school and university students of the towns of N'Djamena, Abeché and Doba, which are some of the major cities of Chad. In secondary / high school, the target groups were Seconde (Form 5), Première (Lower Sixth) and Terminale (Upper Sixth) students selected in the following schools: Lycée Bernard Dikwa Garandi of Doba, Lycée Pascal Yodimnadji of Doba, Lycée Franco-Arabe of Abeché, Lycée Littéraire of Walia (formerly Lycée de Walia 2), Lycée du Sacré-cœur of N'Djamena, and Complexe Scolaire Ibnou Cina of N'Djamena. In total, 190 samples of questionnaire were administered to 143 
boys and 47 girls of those classes. The targeted universities were those of Doba and N'Djamena where a total of 70 samples of the questionnaire were administered to 54 boys and 16 girls. The questionnaire comprised eight open-ended questions set in English and French that the subjects just had to tick (see the appendix) depending on their attitudes towards English and their motivation for learning it

\section{Results}

The eight simple questions used to elicit the subjects' attitudes towards the English language and the various reasons why they learn it comprised the following items: their like or dislike of English (Q1), learning English for communication (Q 2), traveling purposes (Q3), working in an English-speaking country (Q4), friendship (Q5), browsing internet sites (Q6), just as a school subject (Q7), and for job purposes (Q8). Table 1 below summarizes the male secondary school learners' answers.

Table 1. Chadian Male Secondary/ High School Learners' Attitudes and Motivation for English

\begin{tabular}{lcl}
\hline Attitudes and reasons for learning English & Number of subjects (N=143) & $\%$ \\
\hline I like English & 122 & 85.31 \\
I dislike English & 21 & 14.68 \\
Communication & 56 & 39.16 \\
Traveling & 49 & 34.27 \\
Friendship & 18 & 12.59 \\
Working abroad & 80 & 55.94 \\
Internet & 25 & 17.48 \\
Academic & 15 & 10.48 \\
Local job opportunities & 88 & 61.54 \\
\hline
\end{tabular}

The table above reveals that male students in Chadian secondary / high schools generally have a positive attitude towards English $(85.31 \%)$. They equally have a high instrumental motivation in learning it, i.e. studying English for job purposes with the oil companies operating in their country (61.54\%), or for working abroad (55.94\%). Learning it for communication (39.16\%) and for travelling purposes (34.27) is also quite significant. Learning English to have friends from English-speaking countries (12.59) and for internet purposes (17.48) is quite low, perhaps because of the almost inexistent internet network in Chad, and because at that level, they do not yet see the necessity of having English-speaking friends. Table 2 which follows lists female secondary / high school learners' attitudes and motivation.

Table 2. Chadian Female Secondary/ High School Learners' Attitudes and Motivation for English

\begin{tabular}{lcl}
\hline Attitudes and reasons for learning English & Number of subjects $(\mathrm{N}=47)$ & $\mathbf{\%}$ \\
\hline I like English & 44 & 93.61 \\
I dislike English & 03 & 06.38 \\
Communication & 23 & 48.94 \\
Traveling & 15 & 31.91 \\
Friendship & 12 & 25.53 \\
Working abroad & 28 & 59.57 \\
Internet & 11 & 23.40 \\
Academic & 07 & 14.89 \\
Local job opportunities & 30 & 63.83 \\
\hline
\end{tabular}

Table 2 shows that, like their male counterparts, Chadian female secondary / high school students have a positive attitude towards English, and are highly instrumentally motivated to learn it. They either study English to have jobs in their country $(63.83 \%)$ or to work abroad $(59.57 \%)$. Indeed, apart from working locally with the oil companies, they can work as English teachers in various primary or secondary schools across the country. Their answers also reveal that, like their male peers, very few female secondary / high school students (14.89\%) learn English because it is a compulsory school subject. As observed with the boys, learning English for communication (48.94\%) and for traveling purposes $(31.91 \%)$ is noticeable with the girls. It can also be noticed that girls are more interested in learning English for internet (23.40\%) than boys (17.48\%). The table below summarizes the male university students' answers. 
Table 3. Chadian Male University Students' Attitudes and Motivation for English

\begin{tabular}{lcc}
\hline Attitudes and reasons for learning English & Number of subjects $(\mathrm{N}=54)$ & $\%$ \\
\hline I like English & 52 & 96.29 \\
I dislike English & 02 & 03.70 \\
Communication & 22 & 40.74 \\
Traveling & 10 & 18.52 \\
Friendship & 6 & 11.11 \\
Working abroad & 34 & 62.96 \\
Internet & 12 & 22.22 \\
Academic & 4 & 07.41 \\
Local job opportunities & 38 & 70.37 \\
\hline
\end{tabular}

At University level, the results are not very different from those of secondary / high schools' participants. They show that male subjects have a positive attitude and a high instrumental motivation for English, i.e. studying it to get jobs locally $(70.37 \%)$, or abroad (62.96\%). An insignificant number of them (07.41\%) learn English because it is a compulsory subject. Compared with their secondary / high school fellow countrymen, their interest in English for communication $(40.74 \%)$ and internet purposes $(22.22 \%)$ is not also negligible. The low percentage in learning the language for internet use may attest to the low level of research by university students in Chad. The low percentage of subjects who learn English for traveling purposes (11.11\%) is also quite striking at this level. Table 4 below, sums up the female students' responses.

Table 4. Chadian Female University Students' Attitudes and Motivation for English

\begin{tabular}{lcc}
\hline Attitudes and reasons for learning English & Number of subjects $(\mathrm{N}=16)$ & $\mathbf{\%}$ \\
\hline I like English & 16 & 100 \\
I dislike English & 00 & 00 \\
Communication & 08 & 50 \\
Traveling & 08 & 50 \\
Friendship & 02 & 12.50 \\
Working abroad & 14 & 87.50 \\
Internet & 02 & 12.50 \\
Academic & 02 & 12.50 \\
Local job opportunities & 15 & 93.75 \\
\hline
\end{tabular}

Like their secondary / high school and male peers, Chadian female university students have a positive attitude towards English (100\%). In addition to studying it for job purposes in their country $(93.75 \%)$ or abroad (87.50\%), they have a strong interest in learning English for communication (50\%) and travelling purposes (50\%), unlike their compatriots whose answers have so far been under scrutiny. As with their male counterparts, their percentages for studying English for friendship (12.50\%) and internet purposes (12.50\%) are so low.

\section{Conclusion}

In conclusion, it comes out that, although Chad was colonised by France and has as official languages French and Arabic, Chadian learners of English generally take it seriously. At secondary / high school and university levels, they have a positive attitude towards that language. Female university students' positive attitude to English reaches $100 \%$. The various findings at all levels indicate that both male and female learners have a strong instrumental motivation in learning the language. As a matter of fact, their compatriots and foreigners who work with oil companies such as Exxon Mobile, Chevron, Petromas, CNPC, or Glencore and whose working language is English are a daily motivation for them. That can be observed in their active attendance to English classes in high schools and their choice to read it as one of their major subjects at higher levels. It is also interesting to notice that very few participants learn English just because it is a compulsory school subject, a situation that could not be imagined some years back. The study's subjects' interest to learn the language for integrative purposes such as travelling or communicating with English-speaking people is also quite significant at all levels. The present study's findings somehow replicate those of Sayadian \& Lashkarian (2010) on Iranian Learners, and those of Eshghienejad (2016) on Kashan University students. So, because of oil drilling in the country, English is seriously on the move in Chad, a factor that the government and curricula/syllabuses designers should seriously take into account in their various education policies. 


\section{References}

Alizadeh, M. (2016). The Impact of Motivation on English Language Learning. International Journal of Research in Education, 1(1), 11-15.

Anderson, L. (2008). Developmental Expectations of English: Focus on Chad. Unpublished M A Dissertation, School for International Training, Brattleboro, Vermont.

Babaee, N. (2012). Motivation in Learning English as a Second Language: A Literature Review. Canadian Journal for New Scholars in Education, 4(1), 1-7.

Brown, H. D. (2001). Principles of language learning and teaching (4th ed.). Englewood Cliff: Pentice Hall.

Cheng, H. F., \& Dornyei, Z. (2007). The use of motivational strategies in language instruction: The case of EFL teaching in Taiwan. Innovation in Language Learning and Teaching, 1, 153-174. https://doi.org/10.2167/illt048.0

Crookes, G., \& Schmidt, R.W. (1991). Motivation: Reopening the research agenda. Language Learning, 41, $469-512$. https://doi.org/10.1111/j.1467-1770.1991.tb00690.x

Djimrassem, T. (2015). Ecole tchadienne et problèmes majeurs. Paris: Edilivres.

Dörnyei, Z. (1994). Motivation and Motivating in the Foreign Language Classroom. The Modern Language Journal, 78(3), 273-284. https://doi.org/10.1111/j.1540-4781.1994.tb02042.x

Dörnyei, Z. (2001). Teaching and researching motivation. Harlow: Longman.

Drbseb, M. M. H. (2015). Motivation and Attitudes towards learning English as a foreign language: A study of Middle East Arab University Students at Leeds University in the UK. International Journal of Scientific and Research Publications, 5(12), 236-57.

Eshghinejad, S. (2016). EFL students' attitudes toward learning English: The case study of Kashan University Students. Cogent Education, 3(1), 1-13. http://dx.doi.org/10.1080/2331186x.2016.1236434

Fen, R., \& Chen, H. (2009). An Analysis on the importance of motivation and strategy in Postgraduate English acquisition. English Language Teaching, 2(3), 93-97.

Gardener, R.C., \& Lambert, W.E. (1972). Attitudes and Motivation in Second Language Learning. Rowley Mass: Newbury House.

Ghazvini, S.D., \& Khajehpour, M. (2011). Attitudes and Motivation in Learning English as a Second Language in High School Students. Procedia Social Behavioural Sciences, 15, 1209-1213. https://doi.org/10.1016/j.sbspro.2011.03.264

Goktepe, F.T. (2014). Attitudes and Motivation of Turkish Undergraduate EFL Students Towards Learning English Language. Studies in English Language Teaching, 2(3), 314-322. https://doi.org/10.22158/selt.v2n3p314

Johnson, K. (2001). An introduction to foreign language learning and teaching. London: Pearson Education Ltd.

Kachru, B.B. (1988). Teaching World Englishes. ERIC /CLL News Bulletin, 12(1), 1-4.

Karahan, F. (2007). Language attitude of Turkish students towards the English language and its use in Turkish context. Journal of Arts and Sciences, 7, 73-87.

Lamb, M. (2007). The impact of school on EFL learning motivation: An Indonesian case Study. TESOL Quarterly, 41(4), 757-780. https://doi.org/10.1002/j.1545-7249.2007.tb00102.x

Lamb, M. (2011). Future selves, motivation and autonomy in long-term EFL learning trajectories. In G. Murray, T. Lamb \& X. Gao (eds.), Identity, Motivation and Autonomy: Exploring their Links. Bristol: Multilingual Matters, pp.177-194.

Mbaiosso, A. (1990). L’éducation au Tchad. Paris: Karthala. France.

Murphey, T., \& Carpenter, C. (2008). The seeds of agency in language learning histories. In P. Kalaja, V. Menez Menezes \& A.-M. Barcelos (eds.), Narratives of learning and teaching EFL. Basingstoke: Palgrave Macmillan, pp. 17-34.

Richards, J.C., \& Schmidt, R. (2002). Longman Dictionary of Language Teaching and Applied Linguistics. London: Routledge.

Sayadian. S., \& Lashkarian, A. (2010). Investigating Attitude and Motivation of Iranian University Learners Toward 
English as a Foreign Language. Contemporary Issues in Education Research, 3(1), 137-147. https://doi.org/10.19030/cier.v3i1.170

Tasgin, A., \& Tune, Y. (2018). Effective Participation and Motivation/ An Investigation on Secondary School Students. World Journal of Education, 8(1), 58-74. https://doi.org/10.5430/wje.v8n1p58

Ushioda, E. (2011). Why autonomy? Insights from motivation theory and research. Innovation in Language Learning and Teaching, 5, 221-232. https://doi.org/10.1080/17501229.2011.577536

Ushioda, E. (ed.). (2013). International perspectives on motivation: Language learning and Professional challenges. Basingstoke: Palgrave Macmillan. https://doi.org/10.1057/9781137000873

World Bank. (2007). Le système éducatif tchadien. Washington, D C: World Bank.

Appendix

\section{STUDENTS' QUESTIONNAIRE}

This questionnaire is for research purposes, and the information obtained through it will serve that purpose only. All the answers should be given in an anonymous way.

(Ce questionnaire est destine aux fins de recherches et les informations obtenues ne serviront qu'à cette fin. Toutes les réponses sont anonymes)

Your Age (Votre âge):

Your sex (Votre sexe):

Male

Female

Your educational level (Votre niveau d'études):

1. Do you like English? Aimes-tu l'anglais? Yes/ oui

No/Non

Dear students, we would like to find out what motivates you to learn English while your country is not an English-speaking country. Please look at the statements below and tick the boxes that correspond to your own opinions. (Chers étudiants, nous voudrions savoir pourquoi vous apprenez l'Anglais alors que votre pays est Francophone. Lizez les raisons ci-dessous et cochez les cases qui correspondent à votre opinion)

\section{I am studying English for the following reasons (j'apprends l'Anglais pour les raisons suivantes):}

2. Because I want to understand English-speaking people (parce que je veux comprendre les Anglophones):

3. Because I may go to Britain or America someday (parce que j'irai un jour en Grande Brétagne ou en Amérique)

4. Because after my studies I may work in an English-speaking country (parce qu'il se pourrait que je travaille dans un pays Anglophone après mes etudes)

5. Because I want to gain friends among English-speaking people (parce que je veux me faire des amis parmi les Anglophones)

6. Because many internet websites are in English (parce que beaucoup de sites internet sont en Anglais)

7. Because it is a compulsory subject at school (parce que c'est une obligatoire à l'école)

8. Because the knowledge of English will help me obtain a job easily (parce que la connaissance de l'Anglais m'aidera à trouver facilement du travail) 